\title{
AMK Ranch Cultural Landscape Study Grand Teton National Park
}

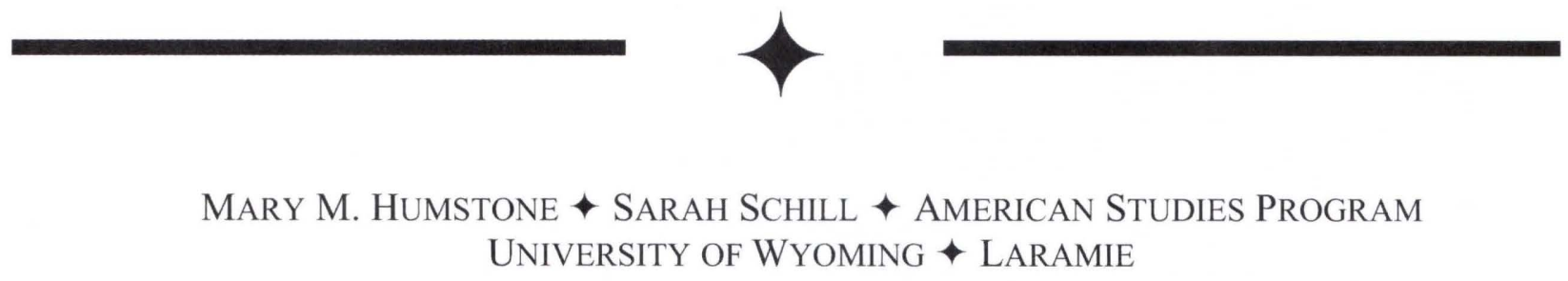

During summer, 2005, the University of Wyoming American Studies Program conducted an intensive cultural landscape survey and analysis at the AMK Ranch. Research Scientist Mary Humstone, working with graduate assistant Sarah Schill, documented the historic buildings and landscape features that tell the history of the Sargents Bay peninsula. The team updated the existing National Register of Historic Places nomination to include detailed building and landscape descriptions and a comprehensive history. The following report is excerpted from the National Register nomination.

\section{Cultural Significance of the AMK Ranch}

The Jackson Hole valley, with its stunning topography and abundant wildlife, has long drawn people for seasonal use, settlement, recreation, and vacation. The history of the AMK Ranch encompasses the various stories that have drawn people to this area, from basic subsistence to vacation. The AMK Ranch is significant as a cultural landscape comprising human settlement on Jackson Lake from 1890 to the modern era, with significant buildings and cultural landscape features that tell the story of the development and use of the peninsula, and represent the larger story of the development of the Jackson Hole valley.

With its history of sustained human habitation extending back to 1890 , the AMK Ranch represents two important phases of settlement in the Jackson Hole valley: homesteading and vacation homes. The property demonstrates a cultural shift from using the land to satisfy basic daily needs, as well as economic sufficiency, to a more dominant appreciation of land as scenery and a place for recreation.

The property is also significant for its well preserved buildings constructed in the Rocky Mountain Rustic style. The buildings retain integrity of materials, workmanship and design, and along with the landscape that surrounds them they convey the feeling and association of an early $20^{\text {th }}$ century vacation property in Grand Teton National Park and contribute to the understanding of the history of this significant property.

\section{John Sargent's Homestead (1890 - 1913)}

The highpoint of the AMK Ranch peninsula marks the site of John Dudley Sargent's original homestead, built in 1890. Forest fires burned extensively in this area in 1856 and 1879 (UW-NPS Site Plan, 11), leaving the peninsula largely uninterrupted by trees when Sargent arrived with his partner, Robert Ray Hamilton. Originally from Machias, Maine, Sargent had traveled back and forth between the East Coast and the West for five years before he settled on Jackson Lake. Hamilton, an independently wealthy New York lawyer, ventured to Wyoming on a hunting trip in May, 1890. Although it is unclear how the two men met, they decided to combine Sargent's experience in the West and Hamilton's connections, both economic and social, to form a partnership and start a dude ranch on the peninsula during the summer of that same year. Sargent seems to have been closer to a land speculator than a farmer, although he did engage in 
subsistence farming. His partnership with Hamilton is a familiar one. "Many who came on hunting trips, bought their own ranches and remained, sometimes in partnership with an accompanying guide from the trip" (Caywood 1997).

By 1891, Sargent had completed a ten-room log house with a sod roof, which he called Marymere, to house his family and the future guests. He also built a barn and corrals, woodshed, chicken house, and boathouse, none of which are extant. Disaster befell Hamilton in August of 1890, before the tenroom house could be completed. Returning alone from an antelope hunt, Hamilton drowned fording the Snake River. Though no evidence supports it, many suspected Sargent of having a hand in the death of his partner. A search party looking for Hamilton finally discovered his body on September $2^{\text {nd }}$ and lit a fire on Signal Mountain, memorializing the event in the name of the mountain.

Sargent's arrival in the Jackson Hole valley coincided with the federal government setting aside land in the greater Yellowstone area to protect the resources. In March of 1891, President Benjamin Harrison created the Yellowstone Park Timber Reserve, consisting of more than one million acres including the northern end of the Jackson Hole valley. This act closed the area to settlement, but Sargent's preemption papers, filed in July 1890, before the creation of the Reserve, enabled him to secure a land patent (Daugherty 120). The Sargent family spent the next six years moving back and forth between Idaho, Wyoming, and Maine, often wintering away from Marymere and spending summers along the shores of Jackson Lake.

Typical of early settlers, Sargent depended upon the immediate environment for his survival, drawing water from the lake, hunting area wildlife, and offering services to passersby to supplement his income. Although Sargent did house travelers and offer boating trips, Marymere never flourished as the intended dude ranch. Instead, Sargent made money where he could, renting out his boat and land for camping, as well as operating a small store. The store, located not far from the homestead on the Army road that ran north to Yellowstone, was likely a "self-serve establishment with a limited inventory" (Diem, 1998).

Tragedy struck the family again in 1897 with the death of Sargent's wife, Adelaide. Controversy surrounds her illness and eventual death, with speculation about Sargent's possible role therein. Whether Adelaide Sargent suffered a lengthy and debilitating illness or broke her leg is impossible to know. Sargent was variously described as too proud, too unfeeling and brutish, or too ignorant of the severity of the illness/break to fetch help (Diem 1986). Eventually, Jackson Hole residents moved the ill Mrs. Sargent from Marymere to D.C. Nowlin's ranch on the present Elk Refuge where she remained until her death two weeks later. Sargent was tried for second degree murder in the death of his wife, though the judge dismissed the case for lack of evidence. The court of public opinion, however, had no doubt that Sargent was an eccentric character at best and a two-time murderer at worst. Sargent's father took custody of the children and severed all ties to John Sargent.

Sargent himself fled east, not returning to Marymere until 1899. He remained largely alone at the ranch for the next six years, operating his small store for supplemental income. He also served as an agent for the Victor Talking Machine Company around 1910 (Diem, 1986:26). Sargent's multiple sources of income are typical of the early homesteader; "a number of homesteaders survived economically by diversifying their sources of income" (Caywood, 1997:22). Sargent mortgaged his ranch for $\$ 1,300$ in 1905 in order to purchase a new herd of milk cows and to marry a woman he met in New York in 1899 during his eastern sojourn (Diem 1986:29).

Edith Drake Sargent, John's second wife, would bring no end to the mysteries and suspicion surrounding Sargent and Marymere. "After the wedding, rumors persisted that Edith was mentally ill and that Sargent was being paid by her family to take care of her" (Diem, 1986:29). Money did pass between Sargent and the Drake family. Edith's brother, Herbert Drake, paid off the \$1,300 mortgage and loaned the couple money. In 1910, Sargent signed the ranch over to Drake (Diem, 1986:29).

Rumors circulated of strange behavior on the ranch. Edith made periodic appearances in the nude and this, coupled with her talent as a violinist, led to one of the more colorful stories associated with the ranch. Three hundred yards northwest of the homestead cabin, a spruce tree with a perfect curve to sit in, grew above a cliff overlooking the lake. Presently known as the "violin tree," this was Edith's favorite spot to come and play the violin. A nail protrudes from the tree where Edith used to hang her bow. Rumor has it that Edith played the violin in the nude, either by preference or because John took her clothes to keep her from straying off the peninsula. 
The isolation brought on by the physical remoteness of the ranch and the long, harsh winters may have intensified any mental illness suffered by John or Edith. Edith commented on her husband's condition: "he was never unbalanced except by melancholia... This trait was inherited and made him live the life of a recluse on his ranch...living alone as he did, so long before our marriage was sufficient to render him, or any man unbalanced" (as quoted in Diem, 1986:31). In a possible effort to erase ties to the past, Sargent changed the name of the ranch from Marymere to Pinetree Ranch and took to using his mother's maiden name, Hemenway, instead of Sargent (Diem, 1986:31).

Edith, having left the ranch in 1912 for California, worried about Sargent's depression and loneliness. These fears proved well founded in the summer of 1913. A party of riders found Sargent dead in his cabin after having shot himself with his rifle some days earlier. Several men buried Sargent in a grave south of his cabin, now surrounded by a log fence. Slim Lawrence constructed this fence in the 1930 s and carved a rock to act as a grave marker for Sargent's burial. Edith eventually died poor in New York City, having spent the last three years of her life hospitalized in the Manhattan State Hospital. Much to Edith's dismay, her brother Herbert Drake was the sole beneficiary of Sargent's estate.

After Drake failed to pay property taxes on the ranch, the County Treasurer sold the property. Between 1918 and 1926, the ranch passed through five different owners. Trappers, including William Cecil "Slim" Lawrence (the eventual caretaker), camped out in Sargent's cabin where they sometimes encountered itinerant livestock. William Lewis Johnson, an executive of the Hoover Company, bought the property in 1926 "for \$1 'and other good and valuable considerations"” (Diem 39).

Although the homestead and other buildings that Sargent built during his tenure on the land are no longer extant, the Sargent era is an important and well documented foundation of the history of the ranch. In evaluating the property as a cultural landscape, it is impossible to ignore Sargent's contributions. In the most basic sense, the AMK Ranch as seen today would not exist if Sargent had not homesteaded this particular 160-acre property. Had it not been for Sargent, this peninsula would have come under federal ownership in 1891, and would not have been developed by private property owners.
Furthermore, Sargent's grave, the approximate location of the homestead, the "violin tree" where Sargent's second wife Edith played the violin and the old military road to Yellowstone, which passed by Sargent's homestead, are features of the cultural landscape, providing a visual link to this era of the peninsula's history.

\section{William Johnson Begins the Vacation Home Era $(1926-1931)$}

The arrival of William Lewis Johnson marked the beginning of the vacation home era at what had been Sargent's homestead. "After World War I, increased publicity of the Grand Teton region, escalating national appreciation for wilderness recreation, improved transportation, and increased leisure hours led to construction of a number of private vacation homes on lands leased from the United States Forest Service. The choicest sites were those near Jackson Lake and the perimeter of the 1929 Grand Teton National Park" (Caywood, 1997:30). Sargent's homestead was an exceptional site, not only for the views it afforded, but also because it was a privately owned holding within the eventual park boundaries.

Johnson, orphaned at the age of ten, had been sent to live at the Miller Manual Labor School in Batesville, Virginia. The school offered free education to a small number of students, many poor or orphaned. The pupils, all male, were also trained in wood and ironwork, the use of steam, and technical drawing (Diem, 1986:35). Though expelled for hazing at the age of sixteen, Johnson apparently felt no ill will towards the school and vowed to "repay the school for all the great things it had done for him" (Diem, 1986:37).

After leaving Miller School, Johnson worked for Bausch and Lomb Optical Company in Syracuse, New York. He left this position at the beginning of World War I to take a job as division manager at Hoover Suction Sweeper Company where he made his fortune. Johnson married Mae Eastman in 1915 and continued to work for Hoover until his retirement in 1926 .

Johnson first saw Jackson Hole while vacationing at Brooks Lake Lodge near Dubois, Wyoming, in the summer of 1923. He fell in love with the area, and stayed in Moran every summer from that point until he bought the Sargent homestead in 1926. Sargent's ranch, "the only private land in the northern end of Jackson Hole," became 
the site for Johnson's second home (Daugherty, 1999:264).

Between 1927 and 1931, Johnson improved his property with numerous log structures. In addition to the main lodge (extended to two stories at the request of Mrs. Johnson, who was afraid of bears) with an attached barn and garage, Johnson bought three structures from a nearby homestead to serve as outbuildings. The Sunroom cabin, the Three Room/Director's cabin, and the Two Room cabin all came from the Hogan homestead and were each purchased for between twenty and fifty dollars. Johnson built a chicken house, woodshed, workshop, smokehouse, boathouse/icehouse and a small log generator house, all of which remain today.

Slim Lawrence and his wife, Verba, caretakers for the Johnsons beginning in 1930, lived in the east section of the Johnson Lodge, which contained its own kitchen, living area, bedroom, and bathroom. The east section has since been converted to house two kitchens, a dining area (formerly the Lawrences' living room), two bedrooms and two bathrooms.

The Johnsons named the property Mae-LouLodge, a combination of Mrs. Johnson's first name and William's middle name. Johnson was passionate about outdoor activities and took advantage of the location of his second home to pursue hunting and fishing. He enjoyed riding and kept about seven horses at the ranch. Arriving in early spring and staying until November allowed Johnson to hunt elk, sage grouse, bighorn sheep, and mule deer. Johnson, often guided by Slim, traveled all over Teton County to hunt. Two Ocean Pass proved good elk hunting ground, and Granite Canyon was home to bighorn sheep. "In between big game trips, Johnson would hunt blue grouse, ruffed grouse and waterfowl around the Jackson Lake area. [Johnson and Slim Lawrence] had blinds set up near Berry Creek where they primarily shot Canada Geese and Canvasback ducks" (Diem, 1986:43). Johnson especially enjoyed bear hunting and made use of Slim's bait stations around Arizona Lake. Johnson placed many of his hunting trophies in the lodge.

Mae Johnson always accompanied her husband to the ranch. Unfortunately, she was only able to enjoy the property for a brief time as her health deteriorated in the late 1920s. Mrs. Johnson died of cancer at a private hospital in Ohio in the fall of 1930 (Diem, 1986z; 44). Johnson did not live much past his wife. On his way home after a big game hunting trip along the Salmon River with Slim,
Johnson fell ill due to a heart disorder. He passed away a month later, on December $8^{\text {th }}, 1931$ (Diem, 1986:44).

In his will, Johnson left $\$ 400,000$ of his nearly one million dollar estate to the Miller Manual Labor School. The Irving Trust Company administered this bequest, as well as the rest of Johnson's estate. In gratitude for all that Johnson had done for them throughout the years, the Miller School dedicated a stone memorial containing the ashes of Mr. and Mrs. Johnson. This memorial, which was dedicated on July 31, 1932, sits just west of the site of Sargent's homestead and north of Sargent's grave (Diem, 1986:44).

The Irving Trust Company held the property from 1931 to 1936, retaining Lawrence as caretaker. During this period, acting on the orders of the Irving Trust and the threat of being fired, Slim Lawrence dismantled and burned the Sargent homestead cabin. "It was the feeling of the Irving Trust that the cabin detracted from the appearance of the site they had selected for the Johnson grave" (Diem, 1986:45).

Slim Lawrence and his wife Verba were the only long-term, year-round residents of the peninsula. Born in 1899, Lawrence grew up in Laramie, Wyoming, helping his father who drove a section of the Laramie-to-Walden stage line. A job with the Lander-Yellowstone Transportation Company brought him to the Jackson Hole area. Slim drove tourists and mail all over Jackson Hole and worked numerous other odd jobs in the off-season until 1930 when he and Verba went to live and work at MaeLou-Lodge as caretakers under the Johnsons.

Slim and Verba spent the next forty years at the ranch on the shores of Jackson Lake, their lifestyle more akin to Sargent's during his homesteading years than that of later owners Johnson and Berol. Year-round living on the remote peninsula presented challenges. The early years, 1930-42, were especially difficult, "characterized by marked winter isolation and heavy physical exertion" (Diem, 1986:70). After turning off the water in December, the Lawrences had to melt snow or haul lake water to provide their water supply. It was not until Berol reworked and winterized the water system in 1936 that indoor plumbing became a year-round option.

The couple often traveled fifteen to twenty miles every day on skis or snowshoes to haul supplies, pick up and receive mail, and trap animals. As travel to town was such a laborious chore, the Lawrences hunted, canned their own food, and 
chopped ice from the lake for refrigeration. Jackson Hole had not yet achieved the immense popularity as a tourist destination that it would after World War II, and there were few residents and visitors, especially at the north end of Jackson Lake. The Lawrences enjoyed the isolation afforded by the ranch and the sparse population, but this would soon change.

\section{The Berol Era (1936 - 1974)}

In 1936, Alfred Berolzheimer (changed to Berol during World War II) purchased the 142-acre ranch from the Irving Trust for $\$ 24,300$ (Diem, 1986:47). Berol made his fortune in the family business, the Eagle Pencil Company, and brought a life of upscale parties and recreation to the property. Berol and his wife, Madeline, spent vacations in Wyoming and Montana and enjoyed hunting and wilderness activities. "During one of Alfred's visits to the Montana Miller Ranch, he learned that the Sargent-Johnson property was for sale" and soon purchased it (Diem, 1986:47). The Berols called their new property AMK Ranch, selecting the first letter of each of their names (Alfred, Madeline, and their son, Kenneth).

Both Alfred and Madeline grew up accustomed to a life with servants and prestigious prep schools, and brought certain expectations with them to Jackson Hole. Upon acquiring the peninsula, the Berols immediately hired an architect, George Kosmak of New York, and began plans for an impressive lodge. Construction of the Berol Lodge began in the spring of 1937 and was finished the following fall. Logs came from Arizona Lake meadows, just east of the property. Most of the fireplace rocks came from the Gros Ventre Canyon, with the exception being the master bedroom fireplace, constructed with pink volcanic rock from Idaho.

The 5,200-square-foot Berol Lodge was designed for entertaining, with a large living room with a soaring cathedral ceiling supported by heavy logs, and a long dining room terminating in a polygonal bay, an idea Berol got from a lodge in Canada. Dramatic views of Jackson Lake and Mt. Moran are visible through the large picture windows on the west side of the lodge. Berol Lodge furniture maintained a Western and Southwestern feel. Pine furnishings and American Indian rugs and pottery predominated, and big game trophies hung on the walls. The wing to the north of the living room contained bedrooms for the family members, while a wing extending to the east from the dining room housed the kitchen and servants' quarters. Caretakers looked after the ranch year-round while a cook, two or three maids and a chauffeur-handyman were employed for the summer.

The Berols established a new era of sophistication at the ranch, and a change in emphasis from recreation to entertaining. The family entertained friends and visitors from July to the first of October each year. Guests stayed in the Mae-LouLodge or in the remodeled space above the garage, and then walked, possibly over a boardwalk to protect clothing, to the Berol Lodge for meals and parties. The early years at the ranch were a busy time, with "six to eight parties per month with $12-22$ people in attendance" (Diem, 1986:53).

The Berols added other ranch buildings in the mid 1930s to accommodate their recreation needs. A new pole and frame barn and a log tack cabin were built for the many horses kept for the Berols and their guests. Berol acquired a horse grazing permit in Teton National Forest, just south of Arizona Lake in order to pasture his ten to fifteen horses. In order to provide more accommodations for his hired help and guests, Berol remodeled the upper floor of the Johnson garage and the caretaker's quarters in the Johnson Lodge. Berol added a rolling dock and remodeled the boat house, then built an additional rolling boat dock on Sargents Bay.

Storms on Jackson Lake often eroded sections of shoreline. One such storm occurred just before the completion of the Berol Lodge, instigating a long battle between Berol and the Bureau of Reclamation. Berol wanted the Bureau to lower the maximum level of the lake or to construct cribbing to prevent further erosion; the Bureau and the National Park Service refused. Instead, Berol spent thousands to construct riprap devices along the west shoreline, many of which washed away in a severe storm. "The erosion problem was never resolved but only deferred to the future" (Diem, 1986:51).

Berol pursued his love of hunting in Wyoming and on the AMK Ranch itself. He had a trap shooting range built in the clearing east of Sargent's grave and the Johnson memorial and a rifle range built down by the east dock on Sargents Bay. Berol and his guests made extensive use of these ranges until Berol joined the Jackson Hole Trap Club in the 1960s. Big game hunting also appealed to Berol, and Slim Lawrence would often take him to hunt in the same places he had taken Johnson. 
The nature of the Lawrences' work as caretakers changed with the arrival of the Berol family. Slim and Verba still spent the off-season trapping, hunting, horseback riding, searching for American Indian artifacts, and fishing, but summers were taken up with catering the parties at the Berol Lodge and taking care of the Berols' guests. With the 1950 enlargement of Grand Teton National Park, roads were plowed year-round, eliminating much of the hard winter labor. The Lawrences' years of service to the Berols were rewarded with a house and an acre of land at the ranch. Located southwest of the Director's and Sunroom cabins, the Lawrence house was built in 1968. "Slim and Verba worked hard clearing out trees and brush at their homesite in the spring [of] 1968" (Diem, 1986:86).

Unfortunately, Verba did not live in the house for long. She suffered a stroke in that same year and was afflicted with cancer. When she became too weak to take her favorite walks down to the lakeshore, Slim built Verba a series of benches enabling her to rest along the way. Unable to cope with the debilitating disease, Verba shot herself in the bedroom of the Lawrence house in July of 1970. She is buried next to her husband, who passed away in 1986, by the Johnson memorial, on the ranch they loved and lived on for forty years.

After 38 years of continuous summer residency at the ranch, Alfred Berol died in 1974. Kenneth, as executor of his father's estate, sold AMK Ranch to the National Park Service in 1976 for \$3.3 million. Kenneth Berol still vacations in the area as of the writing of this nomination, though he no longer stays at AMK, which is now a research station.

\section{Architecture at AMK Ranch}

In addition to its historical significance, AMK Ranch is an important example of rustic architecture in Grand Teton National Park. The Rocky Mountain Rustic style evolved from the pioneer vernacular, and is characterized by the use of native timber and stone, crafted by local craftsman using traditional techniques. "Rustic architecture represented the deliberate attempt - usually an architect's deliberate attempt - to convey historical images and to meld man-made resources with their wilderness environment" (Caywood, 1997:41).

Western log architecture is characterized by diverse construction techniques originating in several European countries including Germany, England, France, and Sweden. Settlers carried traditional building techniques with them from Europe and the
East Coast of the United States. The most common adaptations to the arid Western climate were the gable entrance and increased roof slope. These alterations accommodated the large snowfalls. Because the majority of settlers arrived in the West in the late nineteenth and early twentieth centuries, the iron stove, which was widely available after the mid1800 s, almost completely replaced the fireplace for heating and cooking.

Log homestead architecture, meant to be replaced by more durable and elaborate dwellings, soon came to symbolize the nascent and transitory qualities of life in the American West. With wilderness fast disappearing through homesteading, railroad, and land deals, Americans viewed the log cabin through the lens of nostalgia, connecting it with simpler times and a vanishing way of life. The literal connection to the environment through tree and stone as well as the nostalgic qualities of log architecture led to the domination of this style throughout the West.

Between 1927 and 1931, William Johnson improved his property with numerous log structures. His log home was built by local contractor Charlie Fox in the Rocky Mountain Rustic style. Round logs with saddle notched corners and tapered log ends, massive stone fireplaces, knotty pine paneling, burled log brackets and stair banisters and wrought iron hardware are all elements of this popular style.

In addition to the Johnson Lodge and its attached barn and garage, Johnson bought three structures, the Sunroom cabin, the Three Room/Director's cabin, and the Two Room cabin from the nearby Hogan homestead, a practice that was common throughout the Jackson Hole valley. "Vernacular buildings from the early period were also preserved out of practical concerns. Log cabins in particular have often been 'recycled' for other uses... A cabin once lived in might become a saddle house, a chicken coop, or a storage shed" (Caywood, 1997:39-40). Johnson also built a chicken house, woodshed, workshop, smokehouse, and boathouse/icehouse, all of which remain today. These vernacular additions to the ranch, all of them similar in architectural style to the Johnson Lodge, create a visually cohesive complex.

The Berol's added other ranch buildings to accommodate their recreation needs. A new pole and frame barn was built for the many horses kept for the Berol's and their guests, as well as a log tack cabin. In order to provide more accommodations for his hired help and guests, Berol remodeled the upper 
floor of the Johnson garage and the caretaker's quarters in the Johnson Lodge. Berol added a rolling dock and remodeled the boathouse, then built an additional rolling boat dock on Sargents Bay. The vernacular log buildings that Berol added to the complex blend so well with the Johnson-era buildings that it is difficult to tell them apart.

The most opulent and luxurious architectural touches were reserved for the Berol Lodge. Berol, used to the comforts of an upper-class lifestyle, built a lodge to reflect his status. Though only one story in height, the lodge contains 5,200 square feet and maintains a rustic yet airy atmosphere to capture the beauty of the setting. The living room impresses the visitor with towering ceilings supported by heavy logs and large picture windows overlooking Jackson Lake and Mt. Moran. Abiding by the dictates of formal Rustic architecture, the Berol Lodge uses materials both natural and local. Logs came from Arizona Lake meadows, just east of the property. Fireplace rocks were local as well, coming from the Gros Ventre Canyon. The logs represent a visual connection to the vernacular past, recalling the log cabins of early homesteaders. Imitating the building restrictions of early settlers, Rustic architecture highlights local materials, supplementing them with more luxurious items, such as indoor plumbing. Through Rustic architecture, "comfort and luxury coexisted with a vague concept of "roughing it" (Caywood, 1997:41). Massive stone fireplaces, the enormous logs at the entrance, and detailed wroughtiron work express the Rocky Mountain Rustic ideal. The Berol Lodge interprets "western elements in sophisticated ways,...through integration of architecture, interior design, and furnishings" (Caywood, 1997:42).

\section{CONCLUSION}

The AMK Ranch is eligible for listing in the National Register of Historic Places with significance in settlement and architecture. The district's period of significance extends from John Sargent's original homestead in 1890 to the 1950 s when it was used as a vacation home for the Berol family. Significant dates include 1926, when William Lewis Johnson acquired the property and built his own log home at the southern end of the peninsula, and 1936, when Alfred Berol bought the property and began planning an elaborate rusticated log vacation home. In 1976, the Berol family sold AMK Ranch to the National Park Service and it was dedicated as the University of Wyoming-National Park Service Research Station in July, 1978.

\section{Literature Cited}

Betts, R. B. Along the Ramparts of the Tetons: The Saga of Jackson Hole, Wyoming. University Press of Colorado, 1991.

Caywood, J. and A. Hubber. Grand Teton National Park Multiple Property Submission. National Park Service, Grand Teton National Park, 1997.

Daugherty, J. 1999. A Place Called Jackson Hole: A Historic Resource Study of Grand Teton National Park. Moose, WY: Grand Teton Natural History Association, 1999.http://www.cr.nps.gov/history/online books/grte $2 / \mathrm{hrs} . \mathrm{htm}$

Diem, K. L. 1998. A community of scalawags, renegades, discharged soldiers and predestined stinkers? : a history of Northern Jackson Hole and Yellowstone's influence, 1872-1920. Moose, WY: Grand Teton Natural History Association, in cooperation with the University of Wyoming/National Park Service Research Center.

Diem, K. L., L. L. Diem, and W. C. Lawrence. 1986. Tale of dough gods, bear grease, cantaloupe, and sucker oil: Marymere/Pinetree/Mae-Lou/AMK Ranch. University of Wyoming/National Park Service Research Center.

\section{$\downarrow$ RESEARCH SOURCES}

Grand Teton National Park Archaeologist's Office, Moose, Wyoming.

Grand Teton National Park Historian's Office, Moose, Wyoming.

Jackson Hole Historical Society, Jackson, Wyoming.

Teton County Assessor's Office, Jackson, Wyoming. 


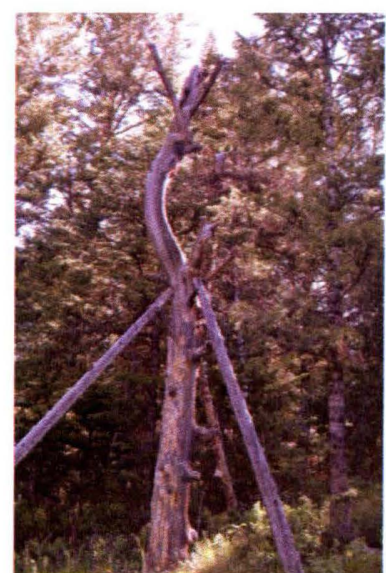

Figure 1. The violin tree located on Sargents peninsula.

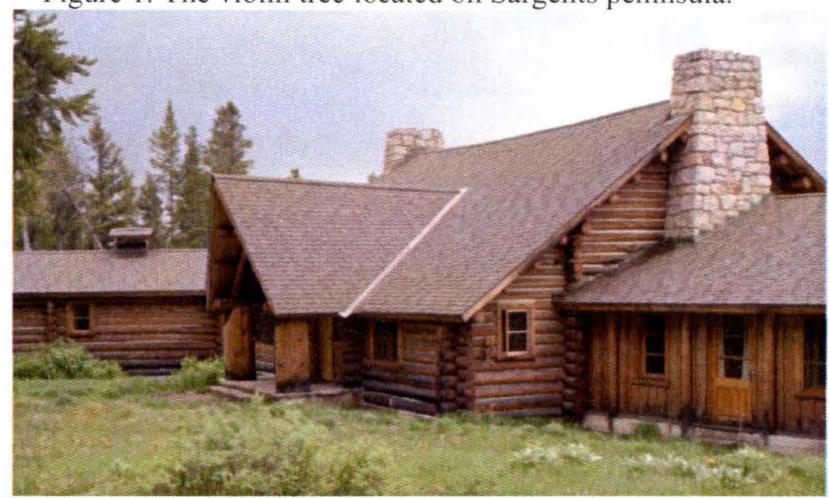

Figure3. The Berol lodge entrance viewed from the north end.

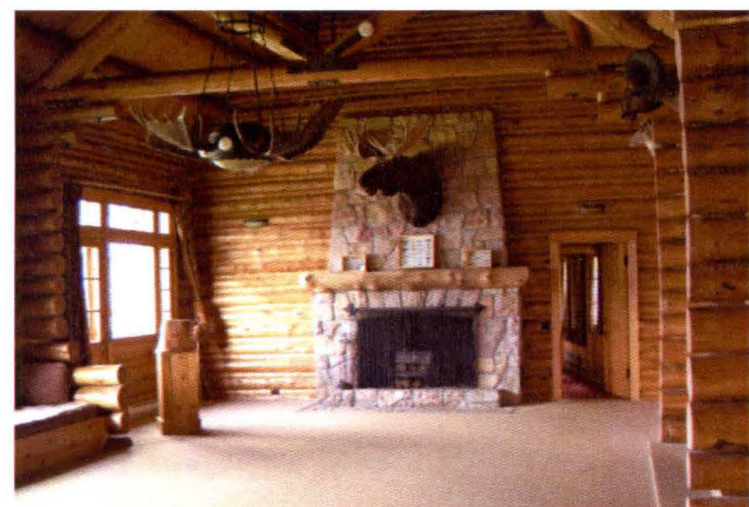

Figure 5. The living room of the Berol lodge.

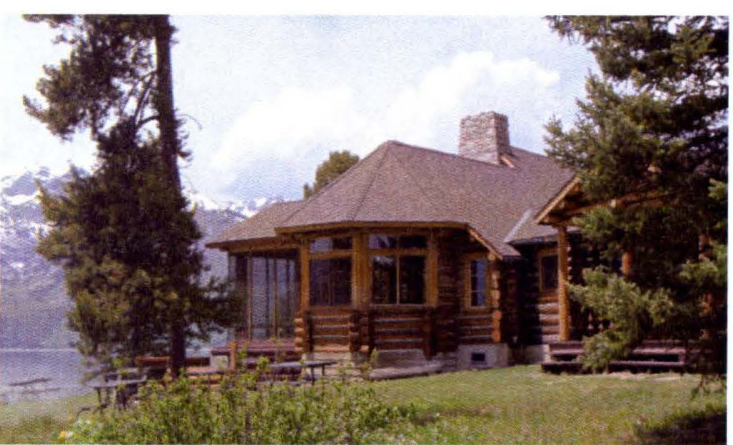

Figure 2. The Berol lodge viewed from the south.

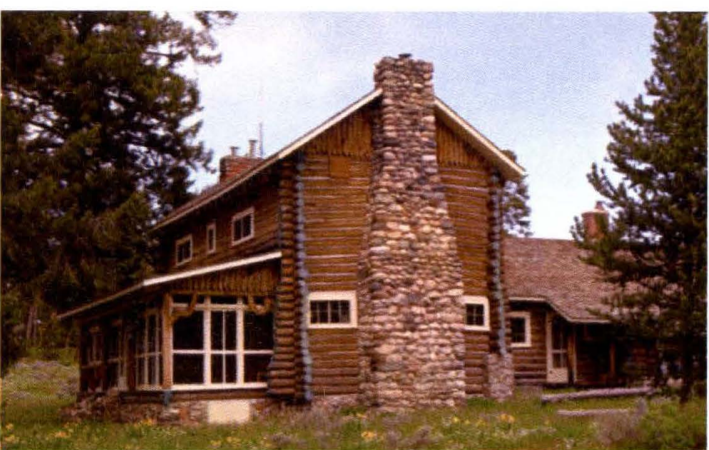

Figure 4. The Johnson (Mae-Lou) Lodge viewed from the south with detail of stone fireplace

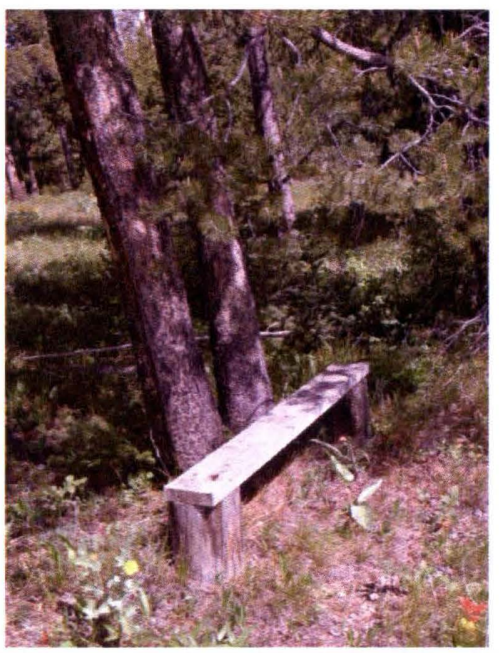

Figure 6. The resting bench built by Slim Lawrence for Verba's walks along the lake shore. 


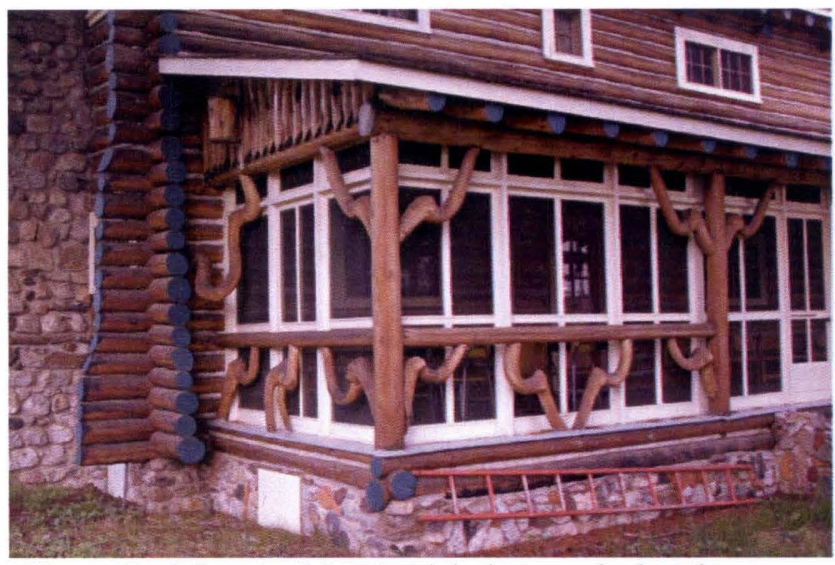

Figure 7. Johnson (Mae-Lou) lodge porch showing detail of $\log$ detailing.

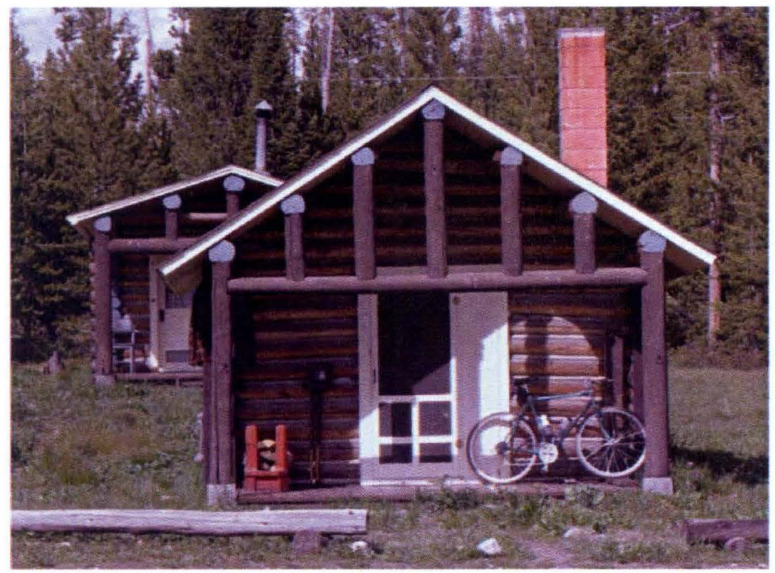

Figure 8. The Shop Cabin and Twin Room Cabin viewed from the west.

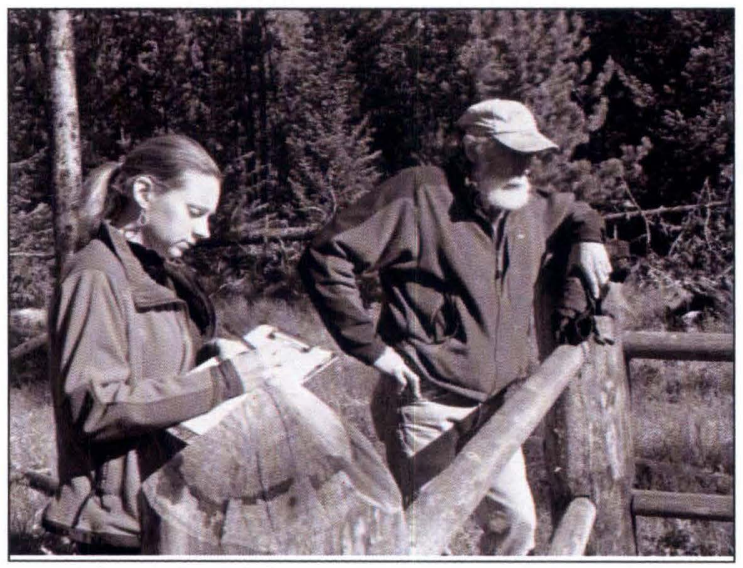

Figure 9. Visitors at John Sargent's grave.

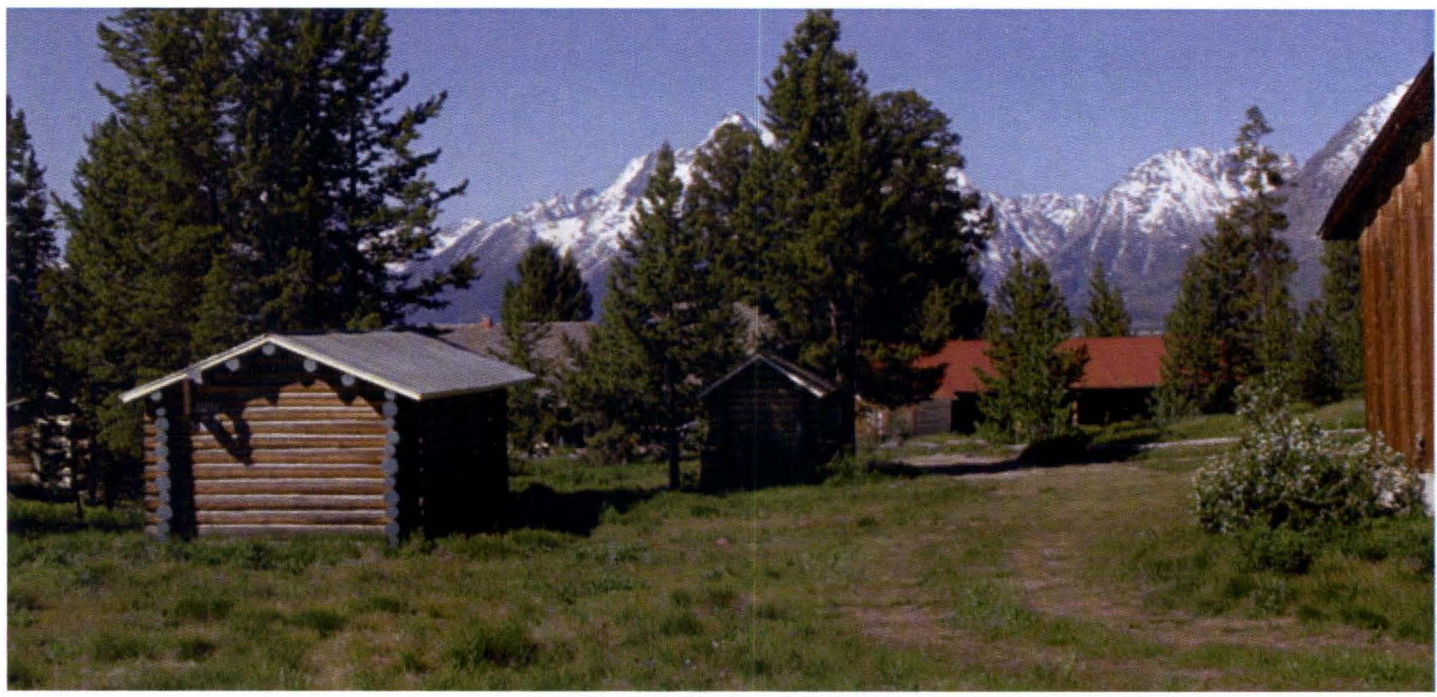

Figure 10. Tack Cabin and Smokehouse on the left, pole barn on the right, wood shed in the far central viewed from the east. 